\title{
PERAN MINAT DAN INTERAKSI SISWA DENGAN GURU DALAM MENINGKATKAN HASIL BELAJAR MATEMATIKA
}

\author{
CHATARINA FEBRIYANTI \\ chatarina022@gmail.com \\ 081398585296
}

\author{
SERUNI \\ taso80@yahoo.co.id \\ Program Studi Pendidikan Matematika, Fakultas Teknik, Matematika, dan IPA \\ Universitas Indraprasta PGRI
}

\begin{abstract}
Abstrak. Tujuan penelitian ini adalah untuk menemukan dan menganalisis secara empiris pengaruh interaksi siswa dan guru dan minat belajar terhadap hasil belajar matematika. Populasi terjangkau pada penelitian ini adalah siswa kelas VII SMP DPN 86 Jakarta Selatan. Sampel penelitian sebanyak 70 yang diperoleh melalui metode random sampling. Rancangan penelitian yang digunakan melalui teknik korelasi dengan tiga variabel yang terdiri dari dua variabel bebas, yaitu interaksi siswa dan guru dan minat belajar serta satu variabel terikat, yaitu hasil belajar matemtika. Pengumpulan data dilakukan dengan teknik kuesioner (variabel interaksi siswa dan guru dan minat belajar) dan teknik tes (variabel hasil belajar). Data yang terkumpul selanjutnya dianalisis menggunakan teknik korelasi dan regresi ganda. Sebelum data dianalisis, terlebih dahulu dilakukan analisis statistik deskriptif dan uji persyaratan data (uji normalitas, uji linearitas, dan uji multikolinieritas). Hasil penelitian menunjukkan bahwa: terdapat pengaruh yang signifikan antara interaksi siswa dan guru dan minat belajar terhadap hasil belajar matematika, dengan koefisien korelasi sebesar 0,877 dan koefisien determinasi 0,768 atau $76,8 \%$ interaksi siswa dan guru dan minat belajar secara bersama-sama mempengaruhi hasil belajar matematika. Persamaan regresi yang dihasilkan $\hat{Y}=-41,565$ $+0,659 X_{1}+0,371 X_{2}$. Hal ini dapat diartikan bahwa semakin baik interaksi siswa dan guru maka semakin baik pula hasil belajarnya dan semakin tinggi minat belajar maka semakin tinggi hasil belajar matematikanya.
\end{abstract}

Kata kunci: interaksi, minat belajar, hasil belajar, matematika

Abstract. The objective of this research is to find and analyze empirically the influence
of student and teacher interaction and interest in learning toward math learning outcomes.
The population in this study is the affordable class VII student DPN 86 South Jakarta. 70
samples are obtained through random sampling method. The research design used
through correlation with three variables consisting of two independent variables, namely
the interaction of students and teachers and the interest in learning as well as the
dependent variable, namely the learning outcomes matemtika. Data was collected through
questionnaire techniques (variable student and teacher interaction and interest in learning)
and test techniques (variable learning outcomes). The collected data were then analyzed
using correlation and multiple regression techniques. Before the data were analyzed, first
performed descriptive statistical analysis and test data requirements (normality test,
linearity, and multicollinearity test). The results showed that: there is a significant
relationship between student and teacher interaction and interest in learning the
mathematics learning outcomes, with a correlation coefficient of 0.877 and a coefficient 
of determination 0.768 or $76.8 \%$ of students and teacher interaction and interest in learning jointly affect learning outcomes mathematics. The resulting regression equation $\mathrm{Y}=-41.565+0.659 \mathrm{X} 1+0.371 \mathrm{X} 2$. This may imply that the better interaction of students and teachers the better the learning outcomes and the higher the higher the interest in learning math learning outcomes.

Keywords: interaction, learning interest, learning outcomes, mathematics

\section{PENDAHULUAN}

Pendidikan merupakan salah satu aspek kehidupan yang sangat penting peranannya dalam usaha membina dan membentuk manusia berkualitas tinggi mengingat begti penting pendididkan, sehingga masalah mutu pendidikan selalu menjadi pusat perhatian yang menyebabkan pemerintah indonesia selalu menekankan penanggulangan yang cermat terhadap kemerosotan pendidikan mulai dari tigkat dasar, tingkat menengah, sampai tingkat pendidikan tinggi. Kemajuan dan perkembangan teknologi tidak dapat dipisahkan dalam kemajuan pendidikan, karena pendidikan dapat meningkatkan kecerdasan, ketrampilan, mempertinggi budi pekerti, memperkuat kepribadian, dan menumbuhkan manusia-manusia pembangunan yang dapat membangun dirinya sendiri serta bersama-sama bertanggung jawab atas pembangunan bangsa.

Untuk dapat mencapai tujuan itu, maka sangat diharapkan secara umum semua warga Negara dan secara khusus siswa-siswi memiliki kemampuan berfikir kritis, terampil, serta kebiasaan untuk menggunakan waktu luang untuk belajar baik disekolah juga dirumah maupun didalam lingkungan masyarakat. Guru juga harus berupaya keras untuk menciptakan suasana yang aman dan tenang yang membuat siswa tertarik dengannya, sehingga dengan tertariknya siswa terhadap guru, akan menimbulkan minat siswa untuk mempelajari apa yang akan diajarkan guru, sehingga hasil belajar siswa meningkat.

Hasil belajar juga banyak dipengaruhi oleh kualitas pengajaran. Guru menguasai banyak faktor yang mempengaruhi motivasi, prestasi dan perilaku siswa mereka. Lingkungan fisik di kelas, level kenyamanan emosi yang dialami siswa dan kualitas komunikasi antar guru dan siswa merupakan faktor penting yang bisa memampukan atau menghambat pembelajaran yang optimal.

Guru bertanggung jawab untuk berbagai siswa, termasuk mereka dari keluarga yang tidak mampu atau kurang beruntung, siswa yang mungkin harus bekerja setelah sekolah, atau mereka yang berasal dari kelompok minoritas etnis, agama atau bahasa atau mereka dengan berbagai kesulitan atau kecacatan belajar. Tak satupun dari situasi atau faktor ini harus menyebabkan masalah pendidikan, namun anak-anak ini mungkin beresiko mendapatkan pengalaman sekolah yang negatif dan tak bermakna jika guru tidak responsif terhadap kebutuhan dan kemampuan mereka atau mampu menggunakan pengajaran dan strategi kelas yang efektif dan disesuaikan menurut individu.

Guru cenderung menunjuk pada kelemahan anak daripada memuji mereka karena upaya dan peningkatan (kecil). Untuk banyak anak ini sangat mengecilkan hati, dan bisa mengakibatkan perasaan rendah diri dan kegagalan. Guru perlu menyadari hal ini. Pengajaran pada umumnya adalah kegiatan kelompok, sedangkan pembelajaran lebih kepada kegiatan individu dan tidak semua siswa belajar dengan kecepatan yang sama atau dengan cara yang sama.

Guru perlu mempertimbangkan berapa banyak kebijakan dan praktek yang mengarah pada labelling siswa. Penelitian tentang interaksi guru-siswa menunjukkan bagaimana guru sering berperilaku berbeda kepada individu siswa berdasarkan pada persepsi mereka sendiri tentang kemampuan siswa. Mereka yang diberi label "berprestasi rendah" atau "siswa lamban belajar" sering menerima sedikit kesempatan dibanding 
orang lain untuk berpartisipasi, dan mereka yang dipandang sebagai "tak disiplin" diperlakukan sedemikian rupa, bahkan ketika mereka berperilaku baik. Guru perlu berefleksi pada asumsi dan ekspektasi mereka dengan meminta feedback dari anak-anak tentang proses belajar-mengajar dan tentang apa yang terjadi di kelas pada umumnya. Semua guru harus melakukan ini seperti yang terungkap pada mereka apa yang dikenali siswa sebagai karekteristik yang berkualitas pada guru, yang hampir tanpa pengecualian berkaitan dengan kemampuan guru untuk mengenali mereka sebagai individu dengan cara positif, memperlakukan mereka dengan adil dan dengan hormat, membuat pelajaran menarik dan beragam, memberikan dorongan dan mengatakan agar mereka meyakini diri mereka sendiri dan kemampuannya.

Ini berarti bahwa hubungan guru-siswa dan iklim kelas yang positif merupakan faktor penting dalam mempengaruhi bagaimana anak mendapat pengalaman bersekolah. Guru tidak hanya mengajar pengetahuan dan keterampilan, mereka juga membantu siswa untuk menjelaskan siapa mereka. Dari interaksi sehari-hari dengan guru, anak belajar mengetahui apakah mereka penting atau tidak, pintar atau lambat, disukai atau tak disukai. Seorang guru mengirimkan pesan-pesan ini melalui perilakunya, gesti, dan katakata. Dari pesan yang diterima anak ini mereka memutuskan untuk meresikokan partisipasi di kegiatan kelas atau tidak. Guru harus mengetahui bahwa keterlibatan tersebut tidak selalu datang dengan mudah dan bahwa ini memerlukan sebuah lingkungan kelas yang nyaman secara psikologis dan dipercaya.

Motivasi untuk belajar dan untuk berperilaku berdasarkan pada minat. Jika guru berhasil merangsang keingintahuan di antara siswa, mereka akan juga menemukan kesediaan di antara siswa untuk belajar dan berperilaku baik. Pengajaran yang memuaskan keingintahuan anak jauh lebih memotivasi dengan efektif daripada memaksa mereka untuk mengerjakan tugas-tugas yang mereka anggap tidak relevan dan membosankan. Oleh karena itu cara guru berinteraksi dengan anak dan cara mengajarnya itu penting dalam mencegah perilaku tak pantas.

Namun, walau upaya interaksi positif itu, masalah perilaku mungkin masih terjadi dan guru harus disiapkan untuk ini dengan berbagai teknik berkisar dari konseling, memfokuskan pada pemahaman, bersama-sama mengatasi masalah perilaku acuh yang tak pantas sambil memberdayakan perilaku yang pantas. Yang penting adalah bahwa guru harus selalu memahami bahwa perilakunyalah yang tak pantas, bukan anaknya! Masalahnya apakah guru dapat melihat melampaui perilaku yang tak pantas itu dan melihat seorang manusia yang patut dihargai. Dengan lulus tes ini akan membuat guru lebih dapat dipercaya, tidak hanya sebagai guru tapi juga, dan lebih penting lagi, sebagai manusia penuh kasih yang tulus.

Menurut Lestari (2013: 117) dukungan minat belajar secara langsung dapat merubah perilaku belajar, dari yang tidak peduli menjadi lebih peduli. Sehingga dengan minat belajar tersebut siswa akan bersedia meninggalkan kegiatan yang kurang mendukung pencapaian tujuan belajar.

Berdasarkan latar belakang masalah, penelitian ini dilakukan di SMP DPN 86 jakarta Selatan. Karena terlihat bahwa hanya sedikit siswa senang berinteraksi dengan guru mata pelajaran matematika dan senang terhadap pelajaran matematika, sebagian besar siswa kurang suka berinteraksi dengan guru mata pelajaran matematika dan kurang menyenangi pelajaran matematika. Sehingga dalam berbagai ulangan baik dalam ulangan harian maupun dalam ulangan umum, hanya siswa yang senang berinteraksi dengan guru mata pelajaran matematika dan senang terhadap matematika saja yang mampu mencapai prestasi gemilang. Dengan demikian peneliti ingin meneliti tentang pengaruh interaksi siswa dengan guru dan minat belajar terhadap hasil belajar matematika. 


\section{TINJAUAN PUSTAKA}

\section{Hakikat Hasil Belajar Matematika}

Menurut Waston (Budiningsih, 2005: ), belajar adalah proses interaksi antara stimulus dan respon, namun stimulus dan respon yang dimaksud harus berbentuk tingka laku yang dapat diamati (observabel) dan diukur. Sedangkan menurut leonard (2013: 100) Belajar adalah sebuah proses perubahan di dalam kepribadian manusia dan perubahan tersebut tercermin melalui peningkatan kualitas dan kuantitas tingkah laku.

Menurut Wittegenstein (Suriasumantri, 2009: ), matematika merupakan metode berpikir yang logis. Berdasarkan perkembangannya maka masalah yang dihadapi logika makin lama makin rumit dan membutuhkan struktur analisis yang lebih sempurna.

Menurut Hakim (2013: 202) Hasil Belajar adalah Kemampuan yang diperoleh anak setelah melalui kegiatan belajar. Hal ini sejalan dengan Sudjana (2002: 112) bahwa "hasil belajar adalah kemampuan - kemampuan yang dimiliki siswa setelah ia menerima pengalaman belajarnya sesuai dengan tujuan pembelajaran yang telah ditetapkan". Dengan demikian dapat dijelaskan bahwa untuk mengetahui seberapa besar tingkat hasil belajar yang telah dilakukan yaitu dengan cara memberikan tes hasil belajar setelah proses pembelajaran selesai.

Menurut Lestari (2013: 118) hasil belajar matematika adalah pola - pola perubahan tingkah laku seseorang yang meliputi aspek kognitif, afektif, psikomotorik setelah menempuh kegiatan belajar mengajar matematika yang tingkat kualitasnya sangat ditentukan oleh faktor yang ada dalam diri siswa dan lingkungan sosial yang mempengaruhinya. Sedangkan Suhendri (2013: 179) menyatakan "hasil belajar matematika adalah puncak dari kegiatan belajar yang berupa perubahan dalam bentuk kognitif, afektif, dan psikomotorik dalam hal kemampuan bilangan, bangun, hubungan hubungan konsep dan logika yang berkesinambungan serta dapat diukur atau diamati”. Senada dengan pendapat Hartati (2013: 229) yang mengatakan "hasil belajar matematika adalah hasil akhir yang dimiliki oleh siswa berupa kemampuan - kemampuan dalam menguasai, memahami konsep dalam pelajaran matematika sebagai ilmutentang logika mengenai bentuk, susunan, besaran dan konsep - konsep yang saling berhubungan satu sama lainnya yang menggunakan istilah serta didefinsikan dengan cermat, jelas dan akurat untuk membantu manusia dalam memahami dan menguasai permasalah sosial, ekonomi, dan alam setelah melalui proses belajar".

Berdasarkan kesimpulan diatas maka dapat disimpulkan hasil belajar matematika adalah kemampuan seseorang untuk memahami permasalahan-permasalahan yang terjadi dalam kehidupan setelah ia mendapatkan proses pembelajaran yang berhubungan dengan konsep - konsep matematika.

\section{Hakikat Interaksi Siswa dan Guru}

Menurut Abu Achmadi dan Shuyadi (Djamarah, 1995: 98) Interaksi adalah suatu gambaran sehubungan aktif dua arah antara guru dan anak didik yang berlangsung dalam ikatan tujuan pendidikan. "Interaksi adalah saling mempengaruhi, hubungan timbal balik antara pihak tertentu misalnya antara guru dan murid".

Didalam proses interaksi antara guru dan murid dalam ke belajar mengajar dibutuhkan sejumlah komponen-komponen atau unsur yang harus ada didalamnya, dimana komponen-komponen itu saling berkaitan dan saling mempengaruhi satu sama lainnya.

Dalam proses interaksi belajar mengajar, anak didik dipandang. bukan hanya sebagai objek pengajaran melainkan juga sebagai Oleh karena itu inti dan proses pengajaran tidak lain adalah aktifitas belajar siswa/anak didik dalam mencapai tujuan atau 
dengan perkataan lain bahwa dalam proses pengajaran atau proses interaksi belajar mengajar yang menjadi persoalan terutama adalah adanya proses belajar mengajar anak yaitu proses dimana anak didik berubah tingkah lakunya melalui berbagai pengetahuan dan keterampilan yang diperolehnya.

Dalam proses interaksi antara guru dan siswa dalam kegiatan belajar mengajar dibutuhkan sejumlah komponen-komponen yang harus ada didalamnya, dimana komponen-komponen itu saling berkaitan antara satu dengan yang lainnya.

Menurut Muhammad Ali (1995:112) keseluruhan komponen-komponen saling berinteraksi dan berhubungan, bersama diarahkan untuk mencapai tujuan. Oleh karena itu menganalisis sistem pengajaran kita harapkan kepada pertanyaan sebagai berikut:

1. Tujuan apa yang hendak dicapai

2. Bahan pelajaran apa yang dipelajari siswa agar dapat mencapai tujuan

3. Metode mengajar apa yang efektif untuk mengantarkan siswa mencapai tujuan

4. Alat pengajaran apa yang relevan untuk membantu mencapai tujuan.

5. Bagaimana melakukan evaluasi untuk menilai keberhasilan pencapaian tujuan.

Dari uraian diatas, maka interaksi antara guru dan siswa adalah suatu jenis tindakan atau aksi yang terjadi antara seseorang yang mengajar dengan seseorang yang belajar, dimana keduanya saling mempengaruhi.

\section{Hakikat Minat Belajar}

Keberhasilan pendidikan seperti yang dicita-citakan oleh setiap lembaga pendidikan adalah ditentukan oleh banyak factor, antara lain bakat, lingkungan belajar, minat, sikap, dsb. Demikian juga dengan keberhasilan belajar matematika ditentukan oleh factor tersebut. Minat adalah suatu kata yang sering diucapkan dalam kehidupan sehari-hari.

Menurut Slameto (2003: 180) minat merupakan suatu rasa lebih suka dan rasa keterikatan pada suatu hal atau aktivitas, tanpa ada yang menyuruh. Dengan kata lain, minat merupakan suatu rasa lebih senang dalam diri seseorang dalam memberikan perhatian yang lebih besar terhadap objek tertentu.

Sedangkan menurut Nasution (2008: 46) bahwa ketekunan belajar ini bertalian dengan sikap dan minat terhadap pelajaran. Bila suatu pelajaran tidak menarik minat seseorang karena sesuatu hal, maka ia segera menyampingkannya jika menemukan kesulitan. Sebaliknya, jika suatu tugas menarik karena memberikan hasil yang menggembirakan, ia cenderung untuk memberikan waktu yang lebih banyak untuk tugas itu.

Menurut Slameto (2003: 58), siswa yang berminat dalam belajar mempunyai ciri ciri sebagai berikut: 1) Mempunyai kecenderungan yang tetap untuk memperhatikan dan mengenang sesuatu yang dipelajari secara terus menerus, 2) Ada rasa suka dan senang pada sesuatu yang diminati, 3) Memperoleh suatu kebanggaan dan kepuasan pada suatu yang diminati. Ada rasa ketertarikan pada sesuatu aktivitas - aktivitas yang diminati, 4) Lebih menyukai suatu hal yang menjadi minatnya daripada yang lainnya, dan 5) Dimanifestasikan melalui partisipasi pada aktivitas dan kegiatan.

Menurut Lestari (2013: 120) menyatakan bahwa minat belajar merupakan dorongan batin yang tumbuh dari seseorang siswa untuk meningkatkan kebiasaan belajar. Dengan demikian yang dimaksud minat belajar adalah keinginan siswa untuk belajar sehingga pada waktu siswa diberi pelajaran ia akan memperhatikan dan aktif berusaha untuk mengetahui dan mengerti pelajaran tersebut. 


\section{METODE}

Penelitian dilaksanakan pada siswa kelas VII SMP Dharma Putra Nusantara 86 Jakarta Selatan. Dimana penelitian ini dilaksanakan selama empat bulan pada bulan Mei Agustus. Penelitian ini merupakan penelitian kuantitatif dengan menggunakan metode survey korelasional dengan desain penelitian di bawah ini:

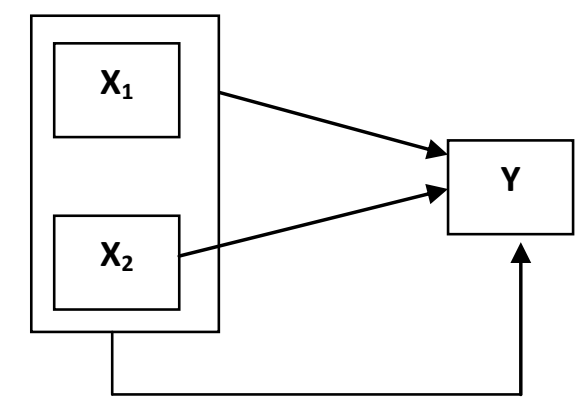

Gambar 1. Desain Penelitian

Keterangan:

$\mathrm{X}_{1} \quad=$ Interaksi Siwa dan Guru

$\mathrm{X}_{2} \quad=$ Minat Belajar Siswa

$\mathrm{Y} \quad=$ Hasil Belajar Matematika

Sampel yang digunakan dalam penelitian ini sebanyak 70 orang siswa, yang diambil dengan teknik random sampling, yaitu dengan membagikan undangan kepada 70 siswa kelas VII yang datang terlebih dahulu. Instrumen yang digunakan adalah angket untuk variabel interaksi siswa dan guru dan variabel minat belajar. Sedangkan untuk hasil belajar dengan menggunakan tes. Analisis pengujian hipotesis menggunakan teknik korelasi dan regresi ganda. Sebelum data dianalisis, terlebih dahulu dilakukan analisis statistik deskriptif dan uji persyaratan data (uji normalitas dan uji linieritas).

\section{HASIL DAN PEMBAHASAN}

\section{Data interaksi siswa dan guru}

Setelah dilakukan pengukuran pada sampel sebanyak 70 siswa didapat mean 100,71, median 103,50, modus 80 , simpangan baku 15,378, dan varians 236,468 .

\section{Data Minat Belajar}

Setelah dilakukan pengukuran pada sampel sebanyak 70 siswa didapat mean 95,13, median 95, modus 92, simpangan baku 12,908, dan varians 166,606

\section{Data interaksi siswa dan guru}

Setelah dilakukan pengukuran pada sampel sebanyak 70 siswa didapat mean 60,10, median 56, modus 56, simpangan baku 15,785 , dan varians 249,164

\section{Uji Persyaratan Data}

Data yang sudah dikumpulkan lalu dilakukan uji normalitas dan linieritas. Setelah dilakukan uji normalitas dengan menggunakan uji chi kuadrat didapat semua berdistribusi normal. Lalu dilakukan uji linieritas maka didapat X1 terhadap Y dan X2 terhadap Y berpola linier 


\section{Pengujian Hipotesis}

Tabel 1. Koefisien Determinasi Interaksi Siswa dan Guru dan Minat Belajar Terhadap Hasil Belajar Matematika

\section{Model Summary}

\begin{tabular}{|l|l|r|r|r|}
\hline $\begin{array}{l}\text { Mode } \\
\perp\end{array}$ & $\mathrm{R}$ & $\mathrm{R}$ Square & \multicolumn{1}{c|}{$\begin{array}{c}\text { Adjusted R } \\
\text { Square }\end{array}$} & $\begin{array}{c}\text { Std. Error of } \\
\text { the Estimate }\end{array}$ \\
\hline 1 & $.877^{\mathrm{a}}$ & .768 & .761 & 7.709 \\
\hline
\end{tabular}

a. Predictors: (Constant), interaksi siswa dan guru, minat belajar

\section{b. Dependent Variable: hasil belajar matematika}

Berdasarkan tabel 1 diperoleh hasil korelasi antara variabel interaksi siswa dan guru dan minat belajar terhadap hasil belajar matematika adalah 0,877 ; yang berarti korelasi antara kedua variabel tersebut tergolong kuat. Koefisien determinasinya sebesar 0,768 atau ada kontribusi sebesar $76,8 \%$ hal ini menunjukan bahwa persentase sumbangan pengaruh variable independen (interaksi siswa dan guru dan minat belajar terhadap hasil belajar matematika) sebesar $23,2 \%$ hasil belajar dipengaruhi oleh faktor lain.

Tabel 2. Signifikan Hubungan Interaksi Siswa dan Guru dan Minat Belajar Terhadap Hasil Belajar Matematika

ANONA $^{\mathrm{b}}$

\begin{tabular}{|ll|r|r|r|r|c|}
\hline \multicolumn{1}{|c|}{} & \multicolumn{1}{c|}{$\begin{array}{c}\text { Sum of } \\
\text { Squares }\end{array}$} & \multicolumn{1}{c|}{ df } & Mean Square & F & Sig. \\
\hline 1 & Regression & 13210.187 & 2 & 6605.093 & 111.132 & $.000^{=}$ \\
& Residual & 3982.113 & 67 & 59.435 & & \\
& Total & 17192.300 & 69 & & & \\
\hline
\end{tabular}

a. Predictors: (Constant), interaksi siswa dan guru, minat belajar

\section{b. Dependent Variable: hasil belajar matematika}

Dari perhitungan diperoleh nilai signifikan 0,000 , hal ini berarti bahwa nilai signifikan hitung lebih kecil dibanding dengan nilai $\alpha=0,05$, dengan demikian dapat disimpulkan bahwa regresi $\mathrm{Y}$ atas $\mathrm{X}_{12}$ adalah sangat signifikan pada taraf $\alpha=0,05$ dan $\alpha=0,01$, sehubungan dengan hasil ini maka dapat dikatakan bahwa koefisien arah regresi nyata sifatnya, sehingga persamaan regresi linear berganda yang diperoleh memiliki keberartian. Begitu pula diperoleh $\mathrm{F}$ hitung $=111,132$, selanjutnya nilai $\mathrm{F}_{\text {tabel }}$ dengan menggunakan tingkat keyakinan $95 \%, \alpha=5 \%(0,05)$, df 1 (jumlah variabel -1$)=2$ dan df $2(n-k-1)$ atau $70-2-1=67$ dimana $\mathrm{n}$ adalah banyak data dan $\mathrm{k}$ jumlah variabel independen. Hasil $F_{\text {tabel }}$ diperoleh 3,130. karena $F$ hitung $>F$ tabel atau $(111,132>3,130)$, maka disimpulkan terdapat pengaruh yang signifikan interaksi siswa dan guru dan minat belajar terhadap hasil belajar matematika. 
Tabel 3. Uji Signifikan Koefisien Regresi Ganda

Coefficients $^{2}$

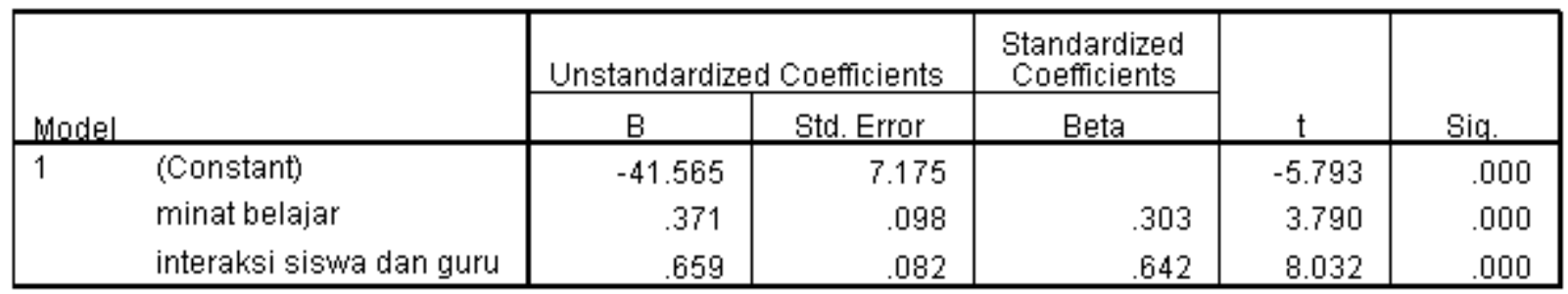

a. Dependent Variable: hasil belajar matematika

Dari tabel 3 dapat disusun persamaan regresi ganda sebagi berikut $\hat{Y}=-41,565+$ $0,659 \mathrm{X}_{1}+0,371 \mathrm{X}_{2}$. Hal ini diartikan bahwa jika variabel bebas di abaikan, maka hasil belajar matematika - 41,565; setiap penambahan 1 point pada interaksi siswa dan guru akan menambah hasil belajar matematika sebesar 0,659; dan setiap penambahan 1 point pada minat belajar akan menambah hasil belajar matematika sebesar 0,371. Pengujian signifikansi regresi menggunakan koefisien sign, dimana sign $=0,000$; yang artinya interaksi siswa dan guru dan minat belajar secara bersama - sama member pengaruh positif dan signifikan terhadap hasil belajar matematika.

\section{Pembahasan}

Berpedoman pada data hasil analisis diketahui bahwa terdapat korelasi yang positif dan signifikan antara interaksi siswa dan guru dan minat belajar secara bersamasama terhadap hasil belajar metematika. Dimana interaksi antara siswa dan guru sangat penting mempengaruhi hasil belajar matematika, interaksi antara siswa dan guru merupakan penentu keseuksesan siswa dalam belajar. Guru yang memiliki professional yang tinggi akan selalu menjalin interaksi yang baik dengan siswanya. Dia selalu memotivasi siswanya dalam belajar untuk mencapai kesuksesannya. Guru dapat memotivasi siswanya dari dua segi: yaitu motivasi intrinsik dan motivasi ektrinsik. Bagi siswa yang selalu memperhatikan materi pelajaran yang diberikan, bukanlah masalah bagi guru. Karena di dalam diri siswa tersebut ada motivasi, yaitu motivasi intrinsik. Siswa yang demikian biasanya dengan kesadaran sendiri memperhatikan penjelasan guru. Rasa ingin tahunya lebih banyak terhadap materi pelajaran yang diberikan. Berbagai gangguan yang ada disekitarnya, kurang dapat mempengaruhinya agar memecahkan perhatiannya. Lain halnya bagi siswa yang tidak ada motivasi di dalam dirinya, maka motivasi ekstrinsik yang merupakan dorongan dari luar dirinya mutlak diperlukan. Di sini tugas guru adalah membangkitkan motivasi siswa sehingga ia mau melakukan belajar.

Selain itu, Guru juga merupakan fasilitator di kelas yang sangat besar pengaruhnya dalam memfasilitasi dan membantu siswa dalam belajar. Siswa akan berhasil dan sukses dalam belajar apabila guru bisa memfasilitasi siswa tersebut dalam belajarnya. Guru yang baik akan menarik banyak perhatian siswa untuk selalu dekat dengannya dan siswa pun tidak ragu dan takut untuk bertanya dan mendiskusikan masalah yang dihadapi dalam belajar kepada guru. Sebaliknya, banyak siswa yang enggan untuk bertanya apa lagi dekat dengan guru dalam belajar karena guru tersebut tidak bisa menarik perhatian siswa. Guru jarang memperhatikan kebutuhan dan keinginan siswa dalam belajar. Bahakan, banyak guru yang jengkel kepada siswanya karena tidak memperhatikan dan tidak sesuai dengan apa yang dia harapkan di kalasnya. Dan sebaliknya, siswa akan merasa jenuh dan bosan dengan guru yang selalu menuntutnya 
untuk selalu mengikuti dan memenuhi apa yang diperintahkan oleh guru tersebut. Dengan adanya hal ini, siswa belum bisa meraih keberhasilan dan kesuksesan dalam belajarnya di kelas.

Minat belajar juga merupakan faktor yang sangat penting dalam mempengaruhi hasil belajar, karena ketika mereka menyukai pelajaran matematika maka siswa dengan sendirinya akan belajar dengan sungguh - sungguh dan siswa akan sangat senang ketika mengikuti pelajaran matematika, sehingga siswa bisa mendapatkan hasil belajar yang sangat baik. Hal ini senada dengan mutakin (2011: 80) yang mengatakan "terdapat pengaruh minat belajar terhadap hasil belajar matematika". Dan lestari (2013: 124) mengatakan "seseorang dengan minat belajar yang tinggi tidak akan menjadikan hambatan sebagai halangan atau kendala dalam belajar, mereka yang berminat tinggi tidak akan mengalami kendala dalam belajar di waktu kapan pun baik pagi maupun siang”. Dengan kata lain, ketika seseorang memiliki minat belajar yang sangat tinggi maka mereka akan lebih bisa menontrol dirinaya sendiri, sehingga mereka dapat meningkat hasil belajar mereka. Sedangkan seseorang yang memiliki minat belajar renndah, mereka tidak bisa memotivasi dirinya sendiri untuk mendapatkan hasil belajar matematika yang diharapkan.

Interaksi siswa dan guru memiliki ikatan langsung pada minat belajar siswa. Jika interaksi siswa dan guru didukung oleh minat belajar yang positif maka secara langsung akan berpengaruh pada hasil belajar matematika siswa. Semakin besar peran kedua variabel bebas tersebut akan semakin besar perubahan hasil belajar yang dapat dicapai. Artinya semakin besar interaksi siswa dengan guru akan menimbulkan minat belajar pada siswa sehingga siswa dengan mudah mengerti pembelajaran yang telah diberikan oleh guru yang akhirnya siswa dengan mudah mendapat hasil belajar yang cukup memuaskan.

Usaha mempertahankan hasil belajar dan sekaligus meningkatkan hasil belajar yang telah dicapai sebelumnya memang sangat sulit, tergantung dari keinginan pribadi masing-masing. Hasil belajar merupakan produk akhir dari kegiatan belajar. Perbaikan proses belajar pada akhirnya akan berpengaruh pada hasil belajar. Hasil belajar antar siswa sangat beragam. Keragaman tersebut merupakan pengaruh langsung dari keterlibatan siswa dan guru serta minat belajar siswa dalam mengikuti proses belajar.

\section{PENUTUP}

\section{Simpulan}

Pertama, terdapat pengaruh interaksi siswa dan guru terhadap hasil belajar matematika, yang diartikan semakin baik interaksi siswa dan guru maka akan semakin bagus juga hasil belajar matematika. Kedua, terdapat pengaruh minat belajar terhadap hasil belajar matematika, yang artinya semakin siswa berminat dalam mengikuti pelajaran matematika maka hasil belajar matematikanya akan baik pula. Ketiga, terdapat pengaruh secara bersama - sama interaksi siswa daan guru dan minat belajar terhadap hasil belajar matematika, yang artinya semakin baik interaksi siswa dan guru dan semakin tinggi minat belajar siswa secara bersama - sama maka akan semakin baik juga hasil belajar matematikanya.

\section{Saran}

Berdasarkan hasil penelitian, maka saran dan harapan yang peneliti ingin sampaikan adalah sebaiknya guru lebih memperhatikan lagi siswa yang mereka ajar sehingga terjalin interaksi yang positif antara siswa dan guru sehingga meningkat minat belajar siswa, 
siswa lebih memperhatikan apa yang telah diajarkan oleh guru dan lebih meningkatkan lagi minat belajarnya agar memperoleh hasil belajar yang memuaskan.

\section{UCAPAN TERIMA KASIH}

Segala puji syukur atas rahmat Alloh SWT atas kemudahan dan kelancaran dalam proses pembuatan artikel ini. Tak lupa kami sampaikan terima kasih kepada: 1) Bapak kepala sekolah SMP Dharma Putra Nusantara 86 yang telah banyak membantu dalam proses penelitian yang kami lakukan, 2) Bapak dan Ibu guru SMP Dharma Putra Nusantara 86 yang tiada henti - hentinya membantu dan memberikan masukan terhadap penelitian kami, dan 3) Siswa SMP Dharma Putra Nusantara 86 atas kerjasamanya.

\section{DAFTAR PUSTAKA}

Ali, M. 1995. Proses Belajar Mengajar. Bandung: Sinar Baru.

Budiningsih, A. 2005. Belajar dan Pembelajaran. Jakarta: Rineka Cipta.

Djamarah, SB. 1995. Anak Didik dari Interaksi Edukatif. Jakarta: Rineka Cipta.

Hakim, AR. 2013. Pengaruh penggunaan media clock set terhadap hasil belajar matematika. Jurnal Formatif, 3(3): 197-202.

Hartati, L. 2013. Pengaruh gaya belajar dan sikap siswa pada pelajaran matematika terhadap hasil belajar matematika. Jurnal Formatif , 3(3): 224-235.

Leonard. 2013. Kajian peran konsistensi diri terhadap prestasi belajar matematika. Jurnal Formatif , 3(2): 97-104.

Lestari, I. 2013. Pengaruh waktu belajar dan minat belajar terhadap hasil belajar matematika. Jurnal Formatif, 3(2): 115-125.

Mutakin, TZ dan Teti S. 2011. Pengaruh penggunaan media belajar dan minat belajar terhadap hasil belajar matematika. Jurnal Formatif, 1(1): 70-81

Nasution, S. 2008. Berbagai Pendekatan dalam Proses Belajar \& Mengajar. Jakarta: PT. Bumi Aksara.

Slameto. 2003. Belajar dan Faktor-faktor yang Mempengaruhinya. Jakarta: Rineka Cipta.

Sudjana. 2002. Metode Statistika. Bandung: Tarsito.

Suhendri, H. 2013. Penerapan model pembelajaran konstruktif berbasis penemuan terbimbing dalam meningkatkan hasil belajar matematika. Jurnal Formatif , 3(3): 177-183.

Suriasumantri, JS. 2009. Filsafat Ilmu (Sebuah Pengantar Populer). Jakarta: Pustaka Sinar Harapan. 